\title{
地域における役割及び空間的特徵に着目した農貿市場の持続的発展について
}

\author{
- 中国大連市沙河口区を対象として -

\section{SUSTAINABLE DEVELOPMENT OF THE CHINESE FARMERS' MARKET FOCUSING ON ITS SPATIAL FEATURES AND ROLES IN LOCAL COMMUNITY}

- A case study of Shahekou District in Dalian -

\author{
石袁吉*1, 矢口哲也*2 \\ Yuanji SHI and Tetsuya YAGUCHI
}

\begin{abstract}
The Chinese farmers' market has supported people's daily life as an essential facility for providing agricultural products since the late 1980s. Therefore, the sustainability of the farmers' market merits discussion. This paper explores the originality of the farmers' market by investigating the pattern of its spatial features and observing people's various activities and relations there. Results suggest that the space of traditional markets relatively functions as an interactive platform for the social-economic activities of the local community, and this function could be the factor of the sustainable development of the Chinese farmers' market in the future.
\end{abstract}

Keywords: Chinese farmers' market, Dalian, community, social-economic activity 農貿市場，大連市，社区，社会経済活動

1 章 はじめに

\section{1-1 研究背景 ·目的}

1978 年に中国はそれまでの計画経済体制を廃止し、市場経済体制 を導入した。経済活動や居住選択が自由になったため、都市構造も 大きく変化した。職場を中心とした「単位」焦1) という共同体が崩壊し、 新たに「社区」注2) という住民組織の概念が生まれた。市場経済の導 入は、都市化の進行と人口の流動を一層促し、様々な背景を持つ人々 が都市に流入した結果、地域社会の再生が必要となった ${ }^{1)}$ 。

経済体制の転換は同時に農産物売買の自由化につながり、80 年代 後半からその土台として「農貿市場」注3) が誕生した。農貿市場は 30 年以上に渡り、地域の最も重要な農産物・食品供給施設として庶 民の生活を支えてきた。2000 年代に入ると、スーパーマーケット注4) などの台頭により、農貿市場が他の商業施設に代替されるようになっ $た^{2)}$ 。しかし、現在でも農貿市場は人々の様々なニーズに応えており、 中国独自の社会背景において、将来的にも必要不可欠な存在として 存続していくと見られている ${ }^{3)}$ 。

一方、農貿市場を画一的に商業施設として捉えるのは、その魅力 の低減にもつながる。持続的な存続・発展のためにも、政府及び経 営者は場所毎の地域環境を把握し、空間的に農貿市場を認識する必 要がある。さらに、その空間的な場所性から生まれる活動を理解し、
現在の時代背景における地域社会での多様な役割を明らかにしてい かなければならない。

\section{1-2 研究目的・構成}

本研究の目的は、農貿市場という「場所」の「空間的特徵」と「人」 による「社会経済活動」に着目し、両者から導かれる「機能」を明 らかにする。これにより地域社会における独自の役割見出すととも に、持続的な農貿市場の在り方について論じる。具体的には(1)農貿 市場の空間的特徴(2)農貿市場とスーパーマーケットの棲み分け(3)農 貿市場の多様な機能と役割の 3 点について述べる。

\section{1-3 既往研究の整理・本研究の位置付け}

現在の中国で農貿市場の運営管理に関寸る研究は、主に $3 つ の$ 観 点が挙げられる。1つ目は農貿市場のスーパーマーケット化を推進 する観点 ${ }^{4) 5}$ ） 2 つ目は農貿市場の環境・品質を改善しながら維持す る観点 ${ }^{6)}$ 、そして 3 つ目は場所や地域特性に応じて農貿市場のスー パーマーケット化を漸次的に進めていくという観点 ${ }^{7)}$ である。また 農貿市場の配置計画に関する研究では、GIS を利用した陳らの研究 珠海市の市場配置計画 ${ }^{8)}$ がある。他の分野では消費者側の趣向や経 済力を分析した王、張の研究 ${ }^{9)}$ や農貿市場経営のスマート化に関す る饒、王らの研究 ${ }^{10)}$ が挙げられる。

これまでの研究では、農貿市場の経営、管理を中心とする論文は
"1 株)日建設計都市部門 修士（建築学）

"2 早稲田大学理工学術院創造理工学研究科建築学専攻 教授・博士 (建築学)
Urban Project Department, Nikken Sekkei Ltd., M.Arch.

Prof., Dept. of Arch., Graduate School of Creative Science and Engineering, Waseda Univ. Dr.Arch. 
多く存在している。しかし、農貿市場の空間的特徴と周辺環境との 関わりや市場に関わる人々の社会経済活動に着目し、地域における 役割とその持続的発展について考察する論文は見られない。よって 本研究では「空間的視点」と「社会的機能」の 2 つアアプローチによっ て農貿市場の役割と持続性を論じる所に独自性を有する。

\section{2 章 農貿市場の成立背景と変遷及び地域社会との関係性 2-1 農貿市場の成立背景 · 変遷}

計画経済時代の中国では、個人による農産物売買の自由が認めら れず、農家は農産物の販売ができなかった。一方では、都市部の住 民は農産物の購入に悩まされていた ${ }^{4)}$ 。その後 1980 年代半ばに農産 物の統一配給制度は廃止され、1978 年から 1984 年にかけて、農産 物の自由交易の基盤が整えられた。初期では道路沿いでの露天販売 が中心であったため、道路の不正占拠が都市の景観・管理に大きな 悪影響を与えた ${ }^{2)}$ 。このような非正規の販売形態を取り締まるため に、政府は新たな販売拠点として「農貿市場」を計画しはじめた。

\section{$\cdot 1980-1990$ 年代}

農貿市場は主に 1980 年代後半に建設された。国営企業の縮小に伴 い、一部の施設が農貿市場の拠点として再利用されるようになった。 人員削減によって職を失い、小売形態の農作物販売を開始した人も 現れたため、農貿市場は失業者の受け典としても機能していた。

1990 年代半ば以降になると、農貿市場は更に発展した ${ }^{9)}$ 。1985 年 から成長期を迎え、1991 年の都市部での農貿市場は 16, 450 箇所あっ たが、1998 年には 26, 381 箇所にまで増加した ${ }^{11)}$ 。そして同年より「菜 藍子」注5) プロジェクトが開始し、農貿市場は安定した農産物の供給 パイプラインとして確立し始めた。

\section{$\cdot 2000 \sim 2010$ 年代}

2000 年代では農貿市場の衛生状況や管理不足が問題となった。政 府は更なる環境の質の向上を目指し、主に老朽化した建物の修復、 サービス向上のためのインフラ整備に力を入れはじめた。農貿市場 は円熟期を迎えた一方、外国資本の大型商業施設も成長し、農貿市 場は徐々に姿を消しはじめている注6)

しかし、2010 年代では農貿市場の価值が再び注目され、北京のよ

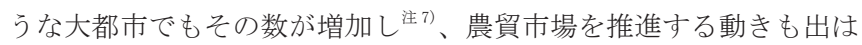
じめてきている。例えば、上海の上海市商務委員会は 2017 年に新た な管理モデルの実行と全市 30 箇所の既存の農貿市場のリノベーショ
ンを目指した ${ }^{12)}$ 。また大連市政府は 2018 年に農産物を売買・交易す る農貿市場の建設、供給範囲の拡大を図る方針を打ち出した ${ }^{\text {注8) }}$

\section{2-2 経済体制の転換による地域社会の変化}

計画経済期の都市部の人々は「単位」に所属していたが、市場経 済の導入により単位制は廃止された。以前単位が提供していた都市 機能やサービスも地域社会に還元され、新しい生活基盤として「社区」 がつくられた。1987 年に「社区服務（社区サービス）」注9) の概念が 政府によって提唱され、1991 年には社区の規模、形式、運営方法な どの骨格が構築された。2000 年には社区の規模、組織構成などの具 体的な基準が定められ、社区は本格的に全国に普及しはじめた ${ }^{10}$ 。 政府は新たな地域密着型のコミュニティの形成を目指し、2006 年に は居住・生活環境の向上、コミュニティ管理の改善、地域社会の問 題解決及び調和した社会づくりを目標として掲げた ${ }^{13)}$ 。

\section{2-3 地域社会と農貿市場の関係性}

上記の目標を達成するために 1991 年より「社区建設 (コミュニティ づくり)」が進められ、基本原則として住民サービスの充実、相互扶 助の推進、地域資源共有などが挙げられた ${ }^{14)}$ 。その過程において、 住民の日常生活と消費活動を支える社区の商業も重要視され、政府 は機能性の充実と利便性の向上、購買圏域の拡大を進めた注 11 。農 貿市場も社区の商業の一環である食料供給拠点として、社区を含め、 単位制崩壊後の地域社会とコミュニティの建設に寄与してきた。

\section{3 章 農貿市場の空間的特徵 \\ 3-1 調査手法・対象}

本章で扱う対象地区は中国の沿岸部に位置する大連市沙河口区で ある。大連市は 1990 年代に 4 番目の開放都市として指定され、他都 市と比較して早期に市場経済への移行が行われた。また対象地区は 中心部にある住宅地で、建て替え中の農貿市場を多く有している。 百度地図での検索及び現地調査により、対象地区内において 32 箇 所の既存農貿市場を確認できた。この内、「販売品目が複数ある」、 「建築物を有する」、「営業中」であるといった条件を満たす 25 箇所 (Fig. 2:A1一G7） 注 12) の農貿市場について空間分析を行う。

農貿市場の特徵を把握するために、基本的な性質の違いを確認す る。現地での目視観察、測量を元に、農貿市場の規模、開放度合、 販売品目に関するデータ (Table 1) ${ }^{\text {注 } 13)}$ を取得し、分類を行った。 販売品目に関して量的データに変換する必要があるため、ダミー変

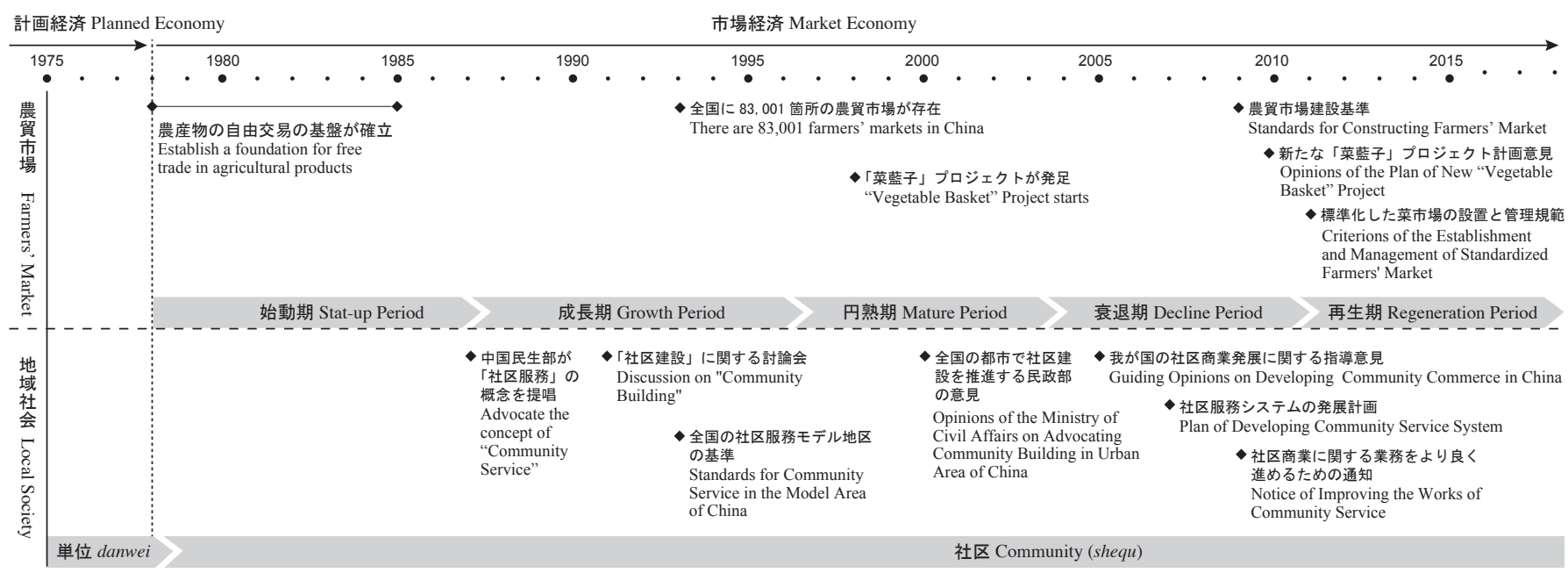

Fig.1 Policies and transition process of the local community and thfarmers' market due to economic system change 


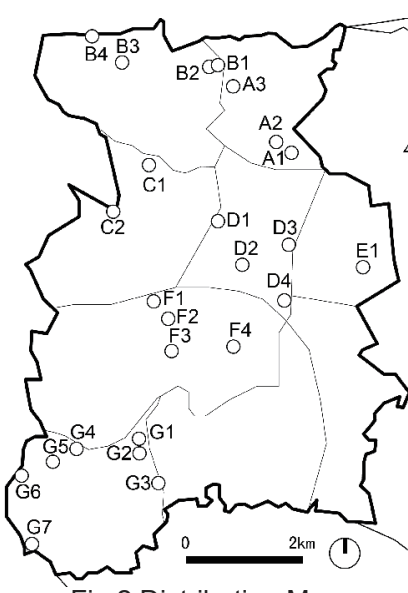

Fig.2 Distribution Map

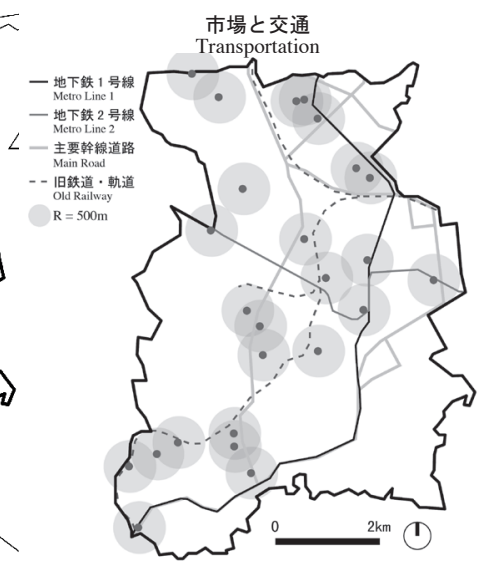

Fig.3 Relationship between geographical conditions and the distribution of farmers' markets
数として数量化 3 類による分析を行う。そして数量化 3 類の值及び Table 1 の指標を用いて、25 箇所の市場に対し、クラスター分析 (ward 法、ユーグリッド距離) を行う。

次に農貿市場の周辺環境を「周辺施設の機能」「都市空間の形態」、 「交通環境」の広域的な側面からそれぞれの特徵と相違を把握する。 用いる指標は Table 3 のように設定し、農貿市場の半径 $800 \mathrm{~m}^{\text {注 }}{ }^{14)}$ を バッファエリアとして分析する。使用するデータについては、高徳 地図より建築階数、道路レベルと長さ、百度地図より POI (Point of Interest）とバス停の位置を取得した。POI には緯度・経度、業務内 容、住所、店名などの情報が含まれ、このデータより各農貿市場の 半径 $800 \mathrm{~m}$ 圈内の施設数 (POI 数) を把握し、その機能を商業、オフィ ス・ビジネス、教育文化、公共、娛楽の 5 つに分類する注 ${ }^{15)}$ 。POI の 機能の多様性はSimpson の多様性指数より求める注 16$)$ 。以上の指標を 使用し、25 箇所の農貿市場の周辺環境に対しクラスター分析 (ward 法、ユーグリッド距離）を行う。

さらに利用者・販売者への聞き込み、ウェブサイトの情報検索及 び現地での目視によって各農貿市場の「建物タイプ」、周辺建物と の関係」、「成立年代」を調査し、建築の特徴としてまとめる。

最後に以上の調查で得られた結果を元に、農貿市場の類型、周辺 環境、建築的特徵を踏まえて、空間的特徵について整理する。

Table 1 Items for cluster analysis

\begin{tabular}{|c|c|}
\hline Category & Analysis Item \\
\hline 規模 Scale & 店舗数 Number of Shops \\
\hline $\begin{array}{l}\text { 開放度合 } \\
\text { Openness }\end{array}$ & $\begin{array}{l}\text { 接道数 Number of Approach Roads } \\
\text { 最大道路幅 Maximum Road Width } \\
\text { 出入口数 Number of Gates }\end{array}$ \\
\hline $\begin{array}{c}\text { 販売品目 } \\
\text { Products for Sale }\end{array}$ & $\begin{array}{l}\text { 青果物 Fruits and Vegetables } \\
\text { 肉類・魚介類 Meat / Seafood } \\
\text { 穀物 Grain ナッツ類 Nuts } \\
\text { 加工食品 Processed Food } \\
\text { 酒・調味料 Liquors / Seasonings } \\
\text { 日用品 Daily Necessities } \\
\text { 服飾 Clothing }\end{array}$ \\
\hline
\end{tabular}

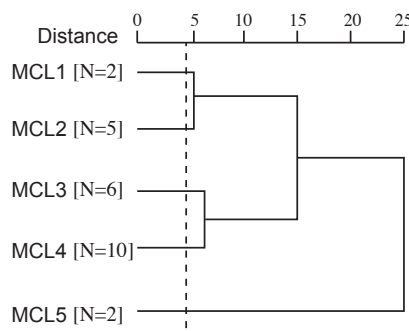

Fig.4 Dendrogram of M-cluster analysis

Table 2 Standardized values for each M-cluster

\begin{tabular}{c|cccccc}
\hline $\mathrm{CL}$ & $\begin{array}{c}\text { 店舗数 } \\
\text { Number of } \\
\text { Shops }\end{array}$ & $\begin{array}{c}\text { 道路本数 } \\
\text { Number of } \\
\text { Roads }\end{array}$ & $\begin{array}{c}\text { 出入口数 } \\
\text { Number of } \\
\text { Gates }\end{array}$ & $\begin{array}{c}\text { 最大道路幅 } \\
\text { Maximum Road } \\
\text { Width }\end{array}$ & $\begin{array}{c}\text { 品目-第1軸 } \\
\text { Product } \\
\text { Axis 1 }\end{array}$ & $\begin{array}{c}\text { 品目-第2軸 } \\
\text { Product } \\
\text { Axis 2 }\end{array}$ \\
\hline 1 & 1.0128 & 1.4881 & 0.1309 & 0.0203 & 0.7916 & 0.1000 \\
\hline 2 & 0.3009 & 0.3019 & 0.5399 & 0.6301 & -0.0598 & -0.1677 \\
\hline 3 & -0.2496 & -0.1294 & -0.4145 & 0.2744 & 0.7916 & 0.1000 \\
\hline 4 & -0.7541 & -0.3451 & -0.4827 & -0.6910 & -0.6929 & 0.0206 \\
\hline 5 & 2.7541 & -0.1294 & 2.1761 & 1.0365 & 0.4475 & -0.0836 \\
\hline
\end{tabular}

\section{3-2 調査結果}

\section{1）農貿市場の分布傾向}

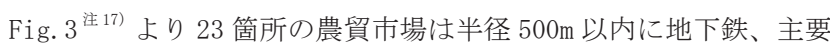
幹線道路、旧鉄道があることがわかる。全体的に農貿市場は住宅地 を中心に、商業地や公共施設の周辺にも位置する。住宅価格は比較 的低く、15000 元 $/ \mathrm{m}^{2}$ 以下が多い。一方南東部の商業・ビジネスが 中心の地域では住宅価格が高く、農貿市場は全く存在していない。

\section{2）農貿市場の類型化}

販売品目について数量化 3 類分析を行なった結果、第 2 軸までの 累積寄与率は $55.1 \%$ となった。第 1 軸を「食品一工芸品」、第 2 軸 を「生活必需品 - 嗜好品」と解釈した ${ }^{\text {ì }}{ }^{18)}$ 。そしてクラスター分析の 結果により、5つのクラスターが得られ、これらを市場クラスター (M-cluster:MCL) と呼ぶ。Fig. 4 にデンドログラムを、Table 2 に各 指標の標準化得点を示し、以下にそれぞれの名称と特徴について述 べる。

\section{MCL1: 大規模半開放全般機能型}

店舗数は 400 前後と規模が大きい。接道本数は最も多いが、出入 口数が中程度、道路幅が比較的狭いので、半開放的と言える。販売 品目は充実していて、種類も多い。

\section{MCL2：中規模開放日常生活機能型}

店舗数は 200-300 で規模が中程度である。接道本数・出入口数は 共に多く、交通量の多い道路と接しているものが多いので、開放的 である。販売品目は生活必需品が多い。

\section{MCL3: 中小規模半開放全般機能型}

店舗数は 100-200 で中小規模である。最大道路幅は大きいが、出 入口数・接道本数が比較的少ないので、半開放的と言える。販売品 目は充実していて、種類も多い。

\section{MCL4：小規模非開放部分機能型}

店舗数は 100 以下で小規模である。歩道や 1 車線道路と接する場 合が多く、接道本数と出入口数は共に少なく、閉鎖的である。食品 は充実しているが、工芸品や嗜好品は少なく、販売品目に偏りがある。 MCL5: 特大規模開放全般機能型

店舗数が 700 以上の超大型市場である。車通りの多い道路に接し、 出入口数も最も多く、非常に開放的である。販売品目は充実していて、 種類も多い。

\section{3）農貿市場の周辺環境}

クラスター分析により、市場の周辺環境は 5 つに分類され、これ 
らを地域クラスター (R-cluster:RCL) と呼ぶ。Fig. 5 にデンドログ ラムを、Fig. 6 にクラスターごとの各指標の最大值・平均值・最小 值を示す。以下にそれぞれの名称と特徴について述べ、Fig. 7 にそ

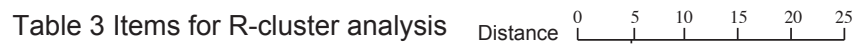

\begin{tabular}{|c|c|}
\hline Category & Analysis Item \\
\hline $\begin{array}{l}\text { 周边機能 } \\
\text { Perineral } \\
\text { functions }\end{array}$ & $\begin{array}{l}\text { POI 総数 Total Number of POI } \\
\text { POI の多様性 Diversity of POI } \\
\text { 各機能 POI の割合 } \\
\text { Ratio of POI for Each Function }\end{array}$ \\
\hline $\begin{array}{l}\text { 空間形態 } \\
\text { Spatial Form }\end{array}$ & $\begin{array}{l}\text { 道路の全長 Total Length of Roads } \\
\text { 周辺建物の階数 } \\
\text { Number of } \\
\text { Buildings }\end{array}$ \\
\hline $\begin{array}{c}\text { 交通環境 } \\
\text { Truftic } \\
\text { Environment }\end{array}$ & $\begin{array}{l}\text { バス停数 Number of Bus Stops } \\
\text { 最奇りバス停までの踤 } \\
\text { Distance to the Closest Bus Stop }\end{array}$ \\
\hline
\end{tabular}

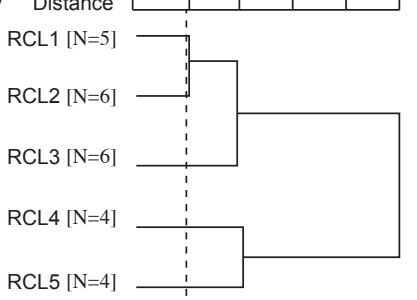

(a)

Fig.5 Dendrogram of

R-cluster analysis
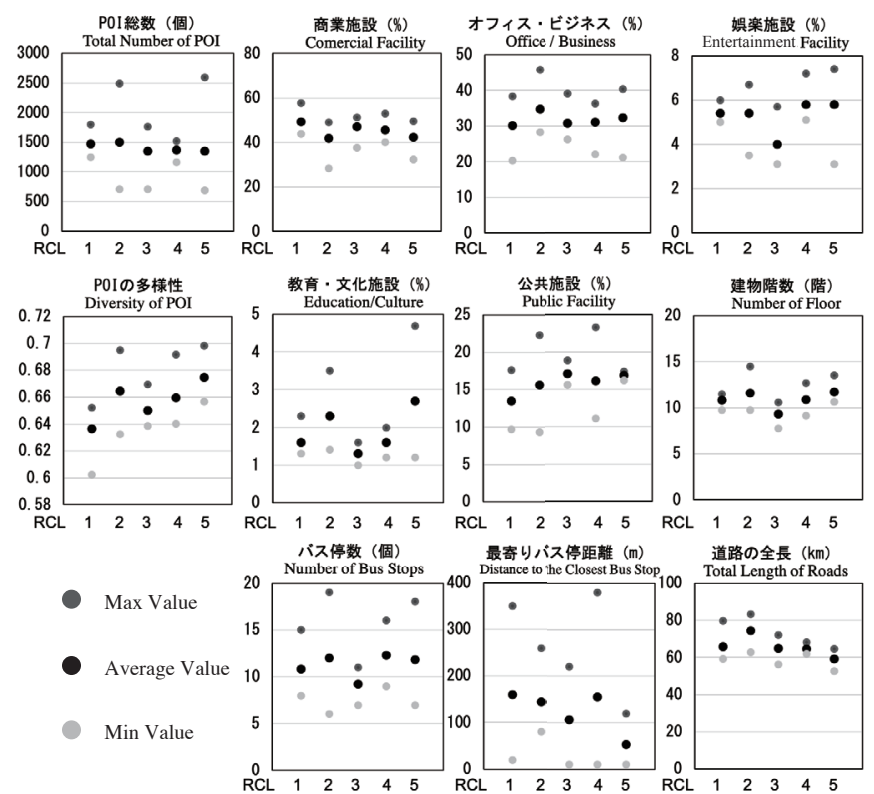

Fig.6 Max, Mean and Min values for each R-cluster
の例及びMCL と RCL の関係を表す。

\section{RCL1：商業・娛楽機能充実型，非交通到達地域}

商業施設・娛楽施設の割合が他の地域より多く、周辺建物の高さと 道路長さは中程度である。バス停数は少なく、最寄りバス停までの 距離は長いので、交通環境があまり良くない。

RCL2: オフィス・ビジネス機能充実型, 交通到達地域

オフィスの割合が他の地域より多く、建物も比較的高い。街路が入 り組んでいるため、道路全長は最も長く、比較的複雑である。農貿 市場周辺のバス停数が最も多いため、交通環境は比較的良好である。 RCL3: 公共機能充実型, 開発停滞·非交通到達地域

公共施設の割合が他の地域より比較的多い。周辺建物の高さは他の 地域と比べて最も低く、不動産開発があまり進んでいない。バス停 数が最も少なく、最寄りのバス停までの距離も比較的長いため、交 通環境があまり良くない。

\section{RCL4: 娛楽機能充実型地域}

娛楽施設の割合は他の地域よりも多いが、他の指標は中程度である。 RCL5: 機能バランス型, 開発進行・交通到達地域

Fig. 6 より、POI の多様性指数の各評価値が 5 つの地域の中で最も高 いため、各機能が最もバランスよく配置されている。周辺建物が高 い一方で、まとまった街区が多いので、道路全長が最も短く、不動 産開発が進んでいると言える。バス停の数が多く、最寄りバスへの 距離も短いので、交通環境が非常に良い。

\section{4）農貿市場の建築的特徵}

農貿市場の建物は主に屋台型、モール型施設、個別建物型の 3 つ が確認され（Fig. 8)、農貿市場の建物と周辺の建物の関係もFig. 9 のように分類できる。また建物と MCL と RCLの関係をそれぞれ Fig. 10, Table 4 で示寸。

\section{3-3 考察}

\section{1）農貿市場の類型と周辺環境の関係}

MCL1, 2 のような中一大規模の農貿市場は比較的古いものが多い。

\begin{tabular}{|c|c|c|c|c|c|c|c|c|c|c|c|c|c|c|c|c|c|c|c|c|c|c|c|c|}
\hline \multicolumn{5}{|c|}{ RCL1 } & \multicolumn{5}{|c|}{ RCL2 } & \multicolumn{5}{|c|}{ RCL3 } & \multicolumn{5}{|c|}{ RCL4 } & \multicolumn{5}{|c|}{ RCL5 } \\
\hline $\begin{array}{r}\text { Distanc } \\
\text { Tot: }\end{array}$ & $\begin{array}{l}\text { to the } \\
\text { Lengtl } \\
\text { Averas }\end{array}$ & $\begin{array}{l}\text { Closest } \\
\text { h of Roa } \\
\text { ge Floor }\end{array}$ & $\begin{array}{l}\text { Bus Stop } \\
\text { ads : } 6604 \\
: 9.7 \mathrm{~F}\end{array}$ & $\begin{array}{l}: 350 \mathrm{~m} \\
77 \mathrm{~m}\end{array}$ & $\begin{array}{r}\text { Distanc } \\
\text { Tota } \\
\end{array}$ & $\begin{array}{l}\text { e to the } \\
\text { al Lengtl } \\
\text { Averag }\end{array}$ & $\begin{array}{l}\text { Closest B } \\
\text { th of Road } \\
\text { ge Floor: }\end{array}$ & $\begin{array}{l}\text { Bus Stop } \\
\text { ds : } 8190 \\
11.0 \mathrm{~F}\end{array}$ & $\begin{array}{l}: 260 \mathrm{~m} \\
06 \mathrm{~m}\end{array}$ & $\begin{array}{r}\text { Distanc } \\
\text { Tota } \\
\end{array}$ & $\begin{array}{l}\text { ce to the } \\
\text { al Length } \\
\text { Averag }\end{array}$ & $\begin{array}{l}\text { Closest } \\
\text { h of Road } \\
\text { ge Floor : }\end{array}$ & $\begin{array}{l}\text { Bus Stop } \\
\text { ds : } 8081 \\
: 8.6 \mathrm{~F}\end{array}$ & $\begin{array}{l}3 \mathrm{~m} \\
3 \mathrm{~m}\end{array}$ & $\begin{array}{r}\text { Distanc } \\
\text { Tota } \\
\end{array}$ & $\begin{array}{l}\text { ce to the } \\
\text { tal Length } \\
\text { Averag }\end{array}$ & $\begin{array}{l}\text { Closest } \\
\text { th of Road } \\
\text { ge Floor : }\end{array}$ & $\begin{array}{l}\text { Bus Stop } \\
\text { Ids : } 6179 \\
: 10.2 \mathrm{~F}\end{array}$ & $\begin{array}{l}: 170 \mathrm{~m} \\
3 \mathrm{~m}\end{array}$ & $\begin{array}{r}\text { Distanc } \\
\text { Tota }\end{array}$ & $\begin{array}{l}\text { ce to the } \\
\text { al Lengt } \\
\text { Averag }\end{array}$ & $\begin{array}{l}\text { Closest } \\
\text { h of Road } \\
\text { ge Floor: }\end{array}$ & $\begin{array}{l}\text { Bus Stop } \\
\text { ds : } 6470 \\
13.5 \mathrm{~F}\end{array}$ & $\begin{array}{l}\mathrm{p}: 50 \mathrm{~m} \\
06 \mathrm{~m}\end{array}$ \\
\hline $\begin{array}{r}\text { POI } \mathrm{EN} \\
\mathrm{EDU} / \mathrm{CL} \\
\mathrm{PL} \\
\mathrm{OFC} / \mathrm{BL} \\
\mathrm{CO}\end{array}$ & $\begin{array}{ll} & 97 \\
\text { L } & 96 \\
\text { B } & \\
& \\
& \end{array}$ & $\begin{array}{r} \\
-316 \\
-4\end{array}$ & 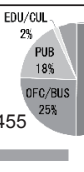 & 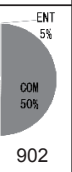 & $\begin{array}{r}\text { POI EN } \\
\text { EDU/CU } \\
\mathrm{PU} \\
\mathrm{OFC} / \mathrm{BL} \\
\mathrm{CO}\end{array}$ & \begin{tabular}{c|c}
$\mathrm{NT}$ & 30 \\
$\mathrm{JL}$ & 12 \\
$\mathrm{JB}$ & $1 \mathrm{C}$ \\
$\mathrm{JS}$ & \\
$\mathrm{M}$ &
\end{tabular} & 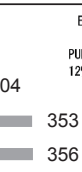 & 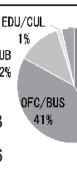 & 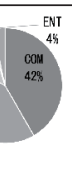 & $\begin{array}{r}\text { POI } \mathrm{EN} \\
\mathrm{EDU} / \mathrm{CU} \\
\mathrm{PU} \\
\mathrm{OFC} / \mathrm{BL} \\
\mathrm{CO}\end{array}$ & \begin{tabular}{c|c} 
NT & 56 \\
UL & 18 \\
UB & \\
US & \\
DM &
\end{tabular} & 316 & 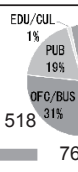 & 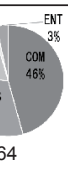 & $\begin{array}{r}\text { POI } \mathrm{EN} \\
\mathrm{EDU} / \mathrm{CU} \\
\mathrm{PU} \\
\mathrm{OFC} / \mathrm{BU} \\
\mathrm{CO}\end{array}$ & \begin{tabular}{c|c} 
NT & 10 \\
UL & 30 \\
UB & \\
US & \\
DM &
\end{tabular} & $\begin{array}{l}66 \\
229 \\
324 \\
\end{array}$ & 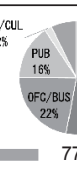 & 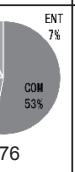 & $\begin{array}{r}\text { POI EN } \\
\mathrm{EDU} / \mathrm{CU} \\
\mathrm{PU} \\
\mathrm{OFC} / \mathrm{BU} \\
\mathrm{CO}\end{array}$ & \begin{tabular}{l|l}
$\mathrm{NT}$ & \\
$\mathrm{JL}$ & $\mathbf{1}$ \\
$\mathrm{JB}$ & \\
$\mathrm{JS}$ & \\
$\mathrm{M}$ &
\end{tabular} & \begin{tabular}{|l}
192 \\
21 \\
\\
\\
$\quad 550$ \\
\end{tabular} & $\begin{array}{c}\text { EDU/CUL } \\
55 \\
\text { PUB } \\
48 \text { 17\% } \\
\text { OFC/BUS } \\
21 \%\end{array}$ & \\
\hline MCL1 & MCL2 & MCL3 & MCL4 & MCL5 & MCL1 & MCL2 & MCL3 & \begin{tabular}{|l|} 
MCL4 \\
\end{tabular} & MCL5 & \begin{tabular}{|l|} 
MCL1 \\
\end{tabular} & \begin{tabular}{|l|} 
MCL2 \\
\end{tabular} & MCL3 & MCL4 & MCL5 & MCL1 & MCL2 & MCL3 & MCL4 & MCL5 & MCL1 & MCL2 & MCL3 & MCL4 & MCL5 \\
\hline A1 & & & \begin{tabular}{|lll} 
B4 & D2 \\
G2 & G4
\end{tabular} & & & $\begin{array}{l}\text { C2 } \\
\text { D5 }\end{array}$ & E1 & \begin{tabular}{|l|} 
C1 \\
G6
\end{tabular} & & B2 & $\begin{array}{l}\text { B1 } \\
\text { F1 }\end{array}$ & 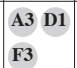 & & & & A2 & B3 & $\begin{array}{l}\text { F4 } \\
\text { G3 }\end{array}$ & & & & G7 & G1 & $\begin{array}{l}\text { D3 } \\
\text { F2 }\end{array}$ \\
\hline
\end{tabular}

Road : $=$ Nationa Road — Provincial Road L Lev.2 Lev. $3 —$ Lev.4 OFC/BUS : Office/Business オフィス・ビジネス EDU/CUL: Education/Culture 教育文化 Floor : $1-4 \mathrm{~F} \longrightarrow 5-9 \mathrm{~F} \longrightarrow 10-14 \mathrm{~F} \longrightarrow 15-24 \mathrm{~F} \longrightarrow 25 \mathrm{~F}-\bigcirc$ Market $\bullet$ Bus Stop PUB : Public 公共 ENT: Entertainment 娛楽 COM : Commercial 商業

Fig.7 Example of each R-cluster 


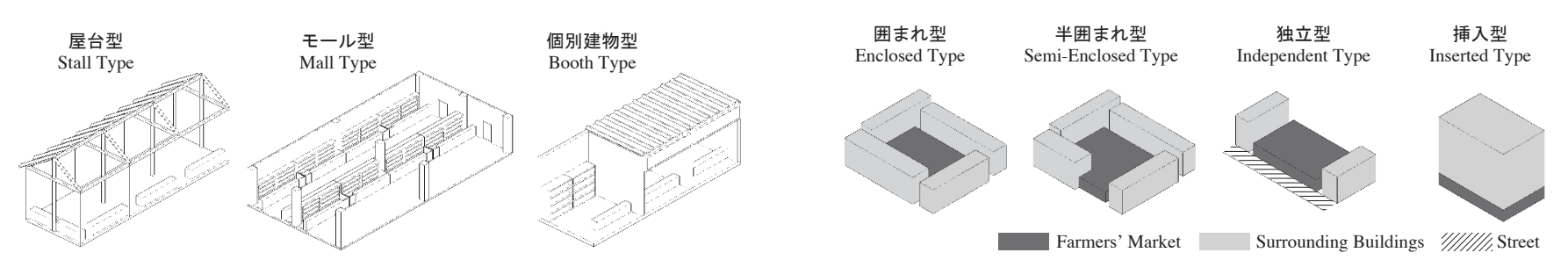

Fig.8 Building typologies of the farmers' market

Fig.9 Relationship between the market and its surrounding buildings

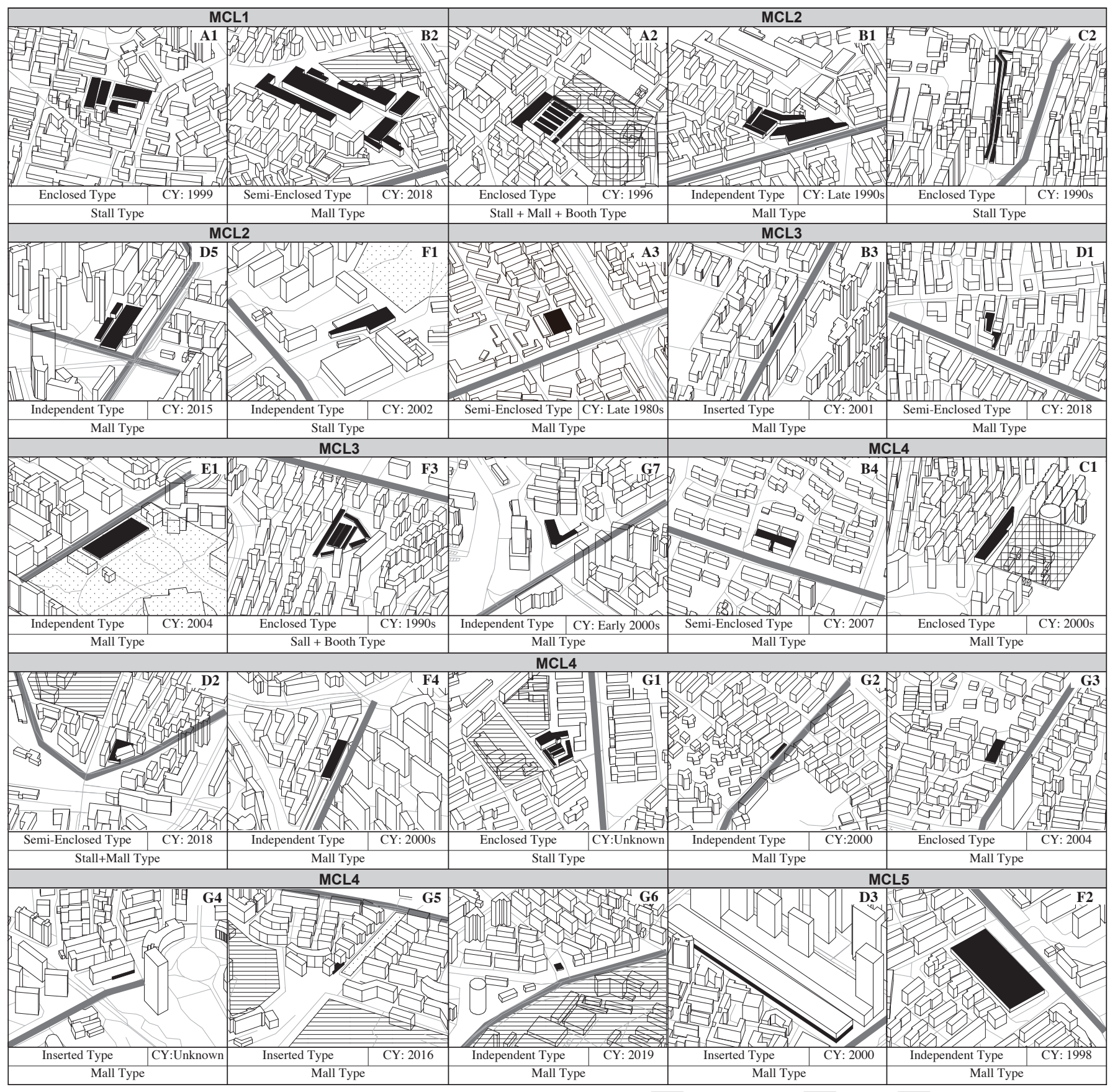

CY: Constructed Year（建設された年代）

Fig.10 Buildings of each farmers' market within city context

Table 4 Relationship between R-Cluster and Buildig Typologies

\begin{tabular}{l|l|l|l|l|l}
\hline Building Type & RCL1 & RCL2 & RCL3 & RCL4 & RCL5 \\
\hline Stall Type & A1(EC) & C2(EC) & F1(ID) & & G1(EC) \\
\hline Mall Type & B4(EC), G2(ID), & $\begin{array}{l}\text { C1(EC), D5(ID)) } \\
\text { E1(ID), G5(I)), } \\
\text { G4(IS) }\end{array}$ & $\begin{array}{l}\text { G1(I), A3(SE) } \\
\text { B2(SE), D1(SE) }\end{array}$ & $\begin{array}{l}\text { B3(IS), F4(ID), } \\
\text { G3(EC) }\end{array}$ & $\begin{array}{l}\text { D3(IS), G7(I), } \\
\text { F2(ID) }\end{array}$ \\
\hline Conplex Type & D2(SE) & & F3(EC) & A2(EC) & \\
\hline
\end{tabular}

EC: Enclosede Type, SE: Semi-Enclosed Type, ID: Independent Type, IS: Inserted Type
低価格で 90 年代前後に建設され、その後再開発されていない住宅に 囲まれている。周辺建物との距離が近く、住民や周辺建物の利用者 が簡単にアクセスできる。また周りに学校、工場、公園と多様な大 きな公共施設が位置している。MCL3 のような中規模市場は様々な地 域クラスターに存在し、場所を問わず一定の需要があると言える。 
MCL4 は機能が不完全な農貿市場であり、商業の割合が高い RCL1 の 地域に多く分布しているため、補足的な地域商業施設だと考えられ る。またそのほとんどが 2000 年代以降に設立されたため、近年の農 貿市場の傾向を表している。 MCL5 のような特大規模市場は地域の中 心的な商業施設であり、主に RCL5 のような交通の便が良く、再開発 が進んでいる地域に位置している。

\section{2）農貿市場の建物タイプと市場の特徵、周辺環境の関係}

Fig.10よりモール型の農貿市場は 20 件あり、スーパーマーケット 化が進行している状況がわかる。年代別で見ると MCL4 のような新し い農貿市場の建物はモール型が目立つ一方、20 年以上前から存在し ている農貿市場には屋台型がよく見られる。旧式の農貿市場は住宅 に囲まれていることが多く（囲まれ型または半囲まれ型）、住民との 距離が比較的近いと考えられる。また市場の規模で見ると MCL1, 2 の ような中一大規模市場の建物は様々なタイポロジーが混合し、規模 が一定以上になると、その空間も多様になっていく (FIg. 10)。

Table 4 より商業機能充実型の RCL1 地域と公共機能充実型の RCL3 地域には 3 つ建物タイプが全て存在しており、周囲の建物との関 係も様々である。両地域ともに開発が進んでいなく、街区形状が比 較的複雑で、公共交通拠点からも離れた場所に位置している。この ような地域環境に対応寸るため、多様な市場空間が展開されている と考えられる。一方 RCL2 のような高層建物が集中しているような地 域では周囲から独立したモール型の農貿市場が多く存在している。

以上より得られた農貿市場の空間的特徵を踏まえた上で、その空 間で展開されている社会・経済活動について着目する。次章では比 較的古く、人々のコミュニティと活動がすでに成立していると考え られる MCL2 の農貿市場を対象とする。

\section{4 章＼cjkstart農貿市場の地域における多様な機能と役割}

前章で明らかにした農貿市場の空間的特徵を踏まえ、本章ではそ こで展開される人々の社会・経済的活動に着目し、農貿市場の様々 な機能と役割について述べる。

\section{4-1 調査概要・対象}

農貿市場は重要な社区の商業サービスであるが、他の商業施設と の違いがあると考えられる。そこで買い物時において、消費者によ る農貿市場とスーパーマーケットの利用状況の違いを明らかにす る。調査は大連市在住者 243 名を対象に web アンケート調查（190
Table 5 Outline of the survey

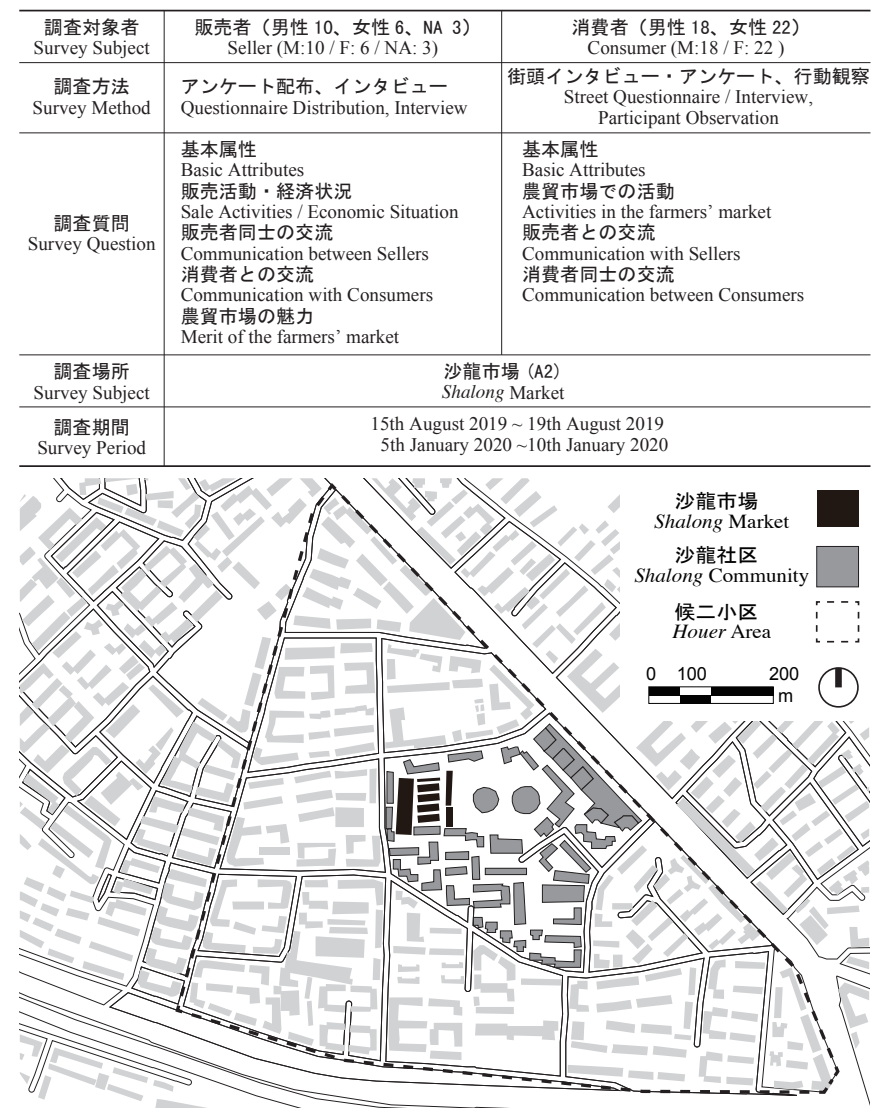

Fig.11 Survey Location

名）、配布式アンケート（社区来訪の春柳街道住民: 53 名）を実施し、 2019 年 11 月 11 日一 2019 年 11 月 18 日に行った。調查内容は基本属性、 消費行動、買い物先の選択理由・購入品及び市場への改善点である。

次に大連市沙河口区春柳街道に位置する「沙龍市場」（A2）を対象 敷地（Fig. 11）とし、農貿市場の販売者と消費者の利用・活動・交流 実態に関する調查を行う（Table 5)。対象敷地はML2 の中でも多様 な建築タイプを有し、周辺において住宅以外にも多様な施設がある (Fig. 10 より)。本市場は 1996 年に、大連房屋財産局の建築資材置 き場を転用してつくられたものである。2019年現在は民間企業によっ て運営され、衛生や環境の改善、建物の改修が進められている一方、 スーパーマーケット化が進行している。
Table 6 Selection factor of shopping facilities Supermarket

\begin{tabular}{|c|c|c|}
\hline Item & Range & $\begin{array}{c}\text { Partial correlation } \\
\text { coefficient }\end{array}$ \\
\hline $\begin{array}{l}\text { 性別 } \\
\text { Gender }\end{array}$ & 0.409897235 & 0.043053787 \\
\hline $\begin{array}{l}\text { 年齢 } \\
\text { Age }\end{array}$ & 2.075274627 & 0.15245406 \\
\hline $\begin{array}{l}\text { 買い物頻度 } \\
\text { Frequency of Shopping }\end{array}$ & 0.849389599 & 0.075388299 \\
\hline $\begin{array}{l}\text { 買い物時間帯 } \\
\text { Time of Shopping }\end{array}$ & 1.70814103 & 0.138185756 \\
\hline
\end{tabular}

\section{Farmers' Market}

\begin{tabular}{|c|c|c|}
\hline Item & Range & $\begin{array}{c}\text { Partial correlation } \\
\text { coefficient }\end{array}$ \\
\hline $\begin{array}{l}\text { 性別 } \\
\text { Gender }\end{array}$ & 0.514097549 & 0.13397587 \\
\hline $\begin{array}{l}\text { 年齢 } \\
\text { Age }\end{array}$ & 0.516997473 & 0.094851545 \\
\hline $\begin{array}{l}\text { 買い物頻度 } \\
\text { Frequency of Shopping }\end{array}$ & 2.942831447 & 0.429402898 \\
\hline $\begin{array}{l}\text { 買い物時間帯 } \\
\text { Time of Shopping }\end{array}$ & 0.361464108 & 0.074136316 \\
\hline
\end{tabular}

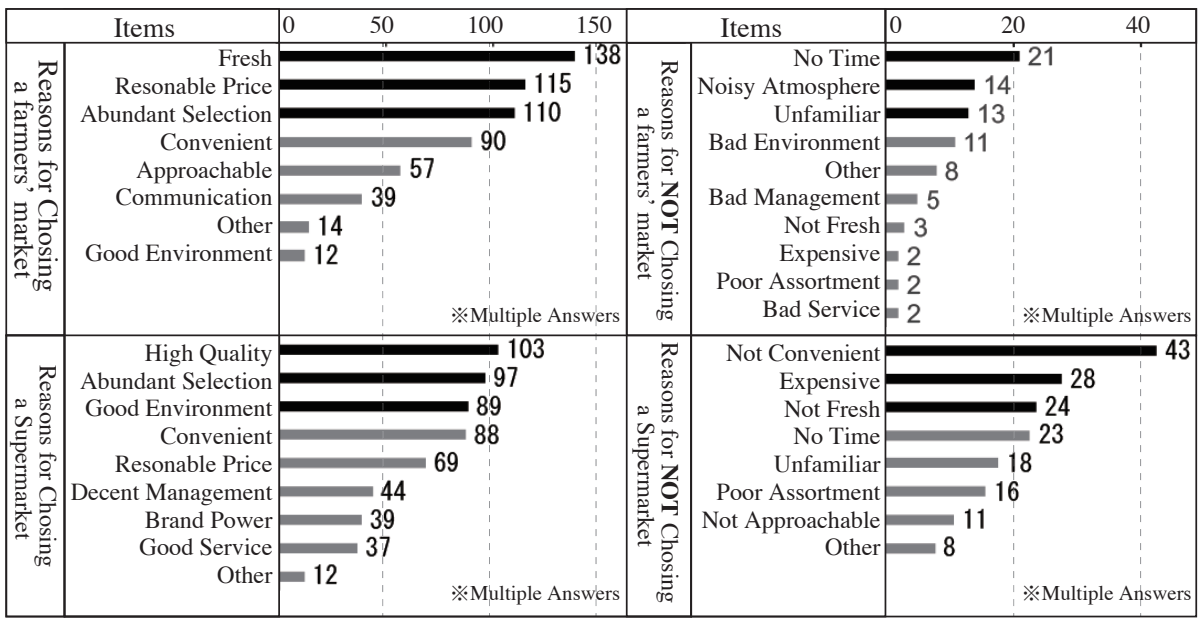

Fig.12 Reasons for choosing or not choosing a supermarket and a farmers' market 


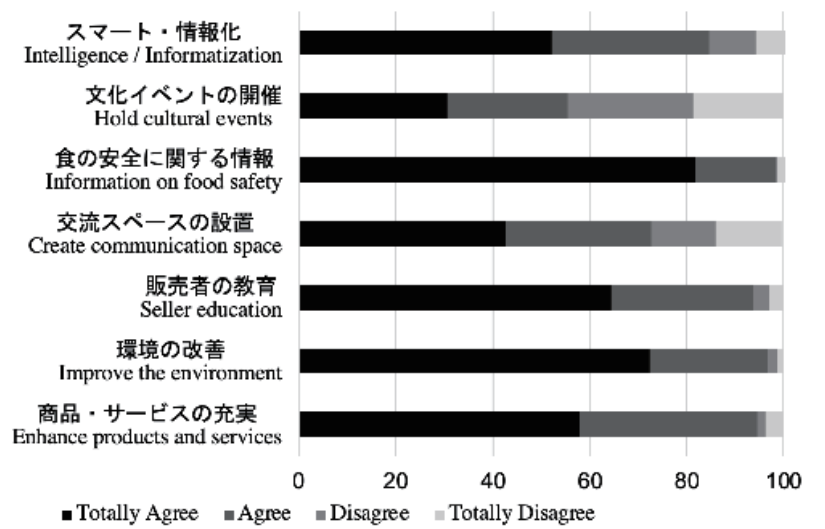

Fig.13 Improvements of farmers' markets

\section{4-2 調査結果}

1）農貿市場とスーパーマーケットの棲み分けについて

(1)属性・消費行動と買い物先の選択

性別、年齢（20 代 -80 代）、買い物頻度（毎日 1 回以上、週に数 回、週に 1 回、月に一回以下)、買い物時間帯（10 時以前、10-14 時、 14 時以降）の 4 項目と買い物先の選択との関係性を分析した（有効 回答数 236)。全体ではスーパーマーケットに行く消費者は約 $64.8 \%$ に対し、農貿市場は $79.7 \%$ である。以上 4 つ項目を説明変数とし、 農貿市場またはスーパーマーケットでの買い物の有無について数量 化 2 類分析を行った。Table 6 より農貿市場の選択に最も影響する 項目は買い物頻度であり、スーパーマーケットの選択においては、 年齢層が最も影響を与える。

年齢層が高くなるに連れ、農貿市場を選択する傾向が見られる。 また買い物頻度が月に 1 回以下の人は農貿市場を利用する割合が約 35\% であり、スーパーマーケットはおよそ $65 \%$ である。一方毎日買 い物する人の $96 \%$ は農貿市場を利用している。上記結果から、買い 物頻度が高い人ほど市場を利用することがわかる。利用の時間帯に 関しては、朝市を中心に午前中に農貿市場を訪れる人が多く、午後 にスーパーマーケットに行く人が多いといら結果となった。

(2)買い物先の選択理由と購入品

次に両者の選択理由に関して、Fig. 12 よりスーパーマーケットを 選択する理由として品質の保証と整った買い物環境が挙げられる。 選択しない理由としてスーパーマーケットは不便で、值段が高く、 食材も新鮮ではないという意見が多い。一方、農貿市場の選択理由 として食材が新鮮で安い点が挙げられ、販売者との值段交渉が自由 にできるのも魅力の 1 つである。農貿市場を選択しない理由として は時間がない、昔ながらの喧騒な䨌囲気が苦手または慣れないなど が挙げられた。他にも金銭トラブルや食の安全性など、信頼性と誠 実性の欠如を理由に、農貿市場を利用したに消費者もいた。また一 部の消費者は農貿市場の方が帰宅途中にある、近所にあると回答し、 消費者にとって農貿市場の方がより身近であることが確認できた。

購入品に関しては、農貿市場は青果物や魚介・肉類などの食材の 購入が中心で、スーパーマーケットでは日用品を主に購入する結果 が得られた。

(3) 農貿市場の改善点

Fig. 13 より、消費者が農貿市場に最も改善してほしいのは食の安 全に関する情報の明示である。次に環境の改善を求めている。一方 交流スペースの設置、文化イベントの開催といった買い物とは異なっ
た側面に関する要望は比較的少なく、全体的に商業施設としての充 実を必要としている。

\section{2）沙龍市場における多様な機能と活動（販売者について） \\ (1) 販売者の属性}

40 代の男性を中心に、農貿市場での販売経歴が 10 年以上の販売 者は半分以上であり、継続的に販売活動を行なっている者が多い。 また 14 人の販売者が沙河口区内に居住し、その内さらに 11 人が農 貿市場周辺の候二小区に居住しており、販売活動が周辺地域への定 住に結びついている。

\section{(2) 販売者の販売活動及び経済状況}

農貿市場での販売活動を通して、約 7 割の販売者が収入の増加が 見られた（Fig. 14）。店舗の規模を拡大させた販売者や、収入の増加 により、大連市内で住宅を購入した販売者もおり、農貿市場での販 売が経済状況の改善につながることがわかった。

農産物の仕入先としては大型卸売市場が多いが、自家栽培や農村 部の農民から直接購入するなど地元の農産物を取扱う販売者もいる。 特に海産物に関しては、大連の近海に養殖場を保有する販売者も存 在し、名産のなまこなどを中心に販売している。

(3) 販売者のサービス提供状況と農貿市場の魅力 (Fig. 15 より)

販売者は顧客数が多く、対面式での販売によって顧客との信頼関 係を築きやすい所に農貿市場の魅力を感じている。多くの消費者と 直接的・定期的に対面するため、消費者の満足度や反応をいち早く 知り、対応できるのもそのメリットである。一方、販売者は妥当な 価格の設定を心がけているが、食材の安全面に配慮が欠けている状 況も見られた。

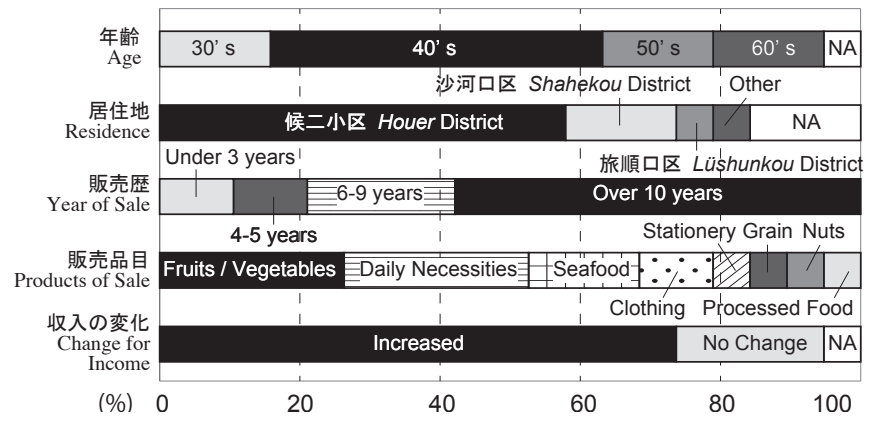

Fig.14 Basic Information about sellers $(n=19)$

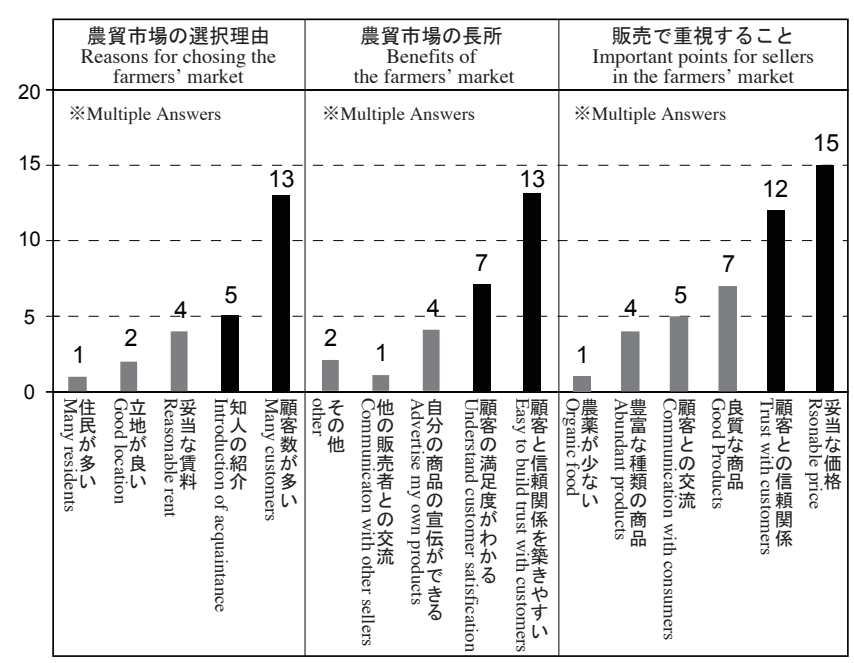

Fig. 15 Merits and sale activities of the farmers' market 


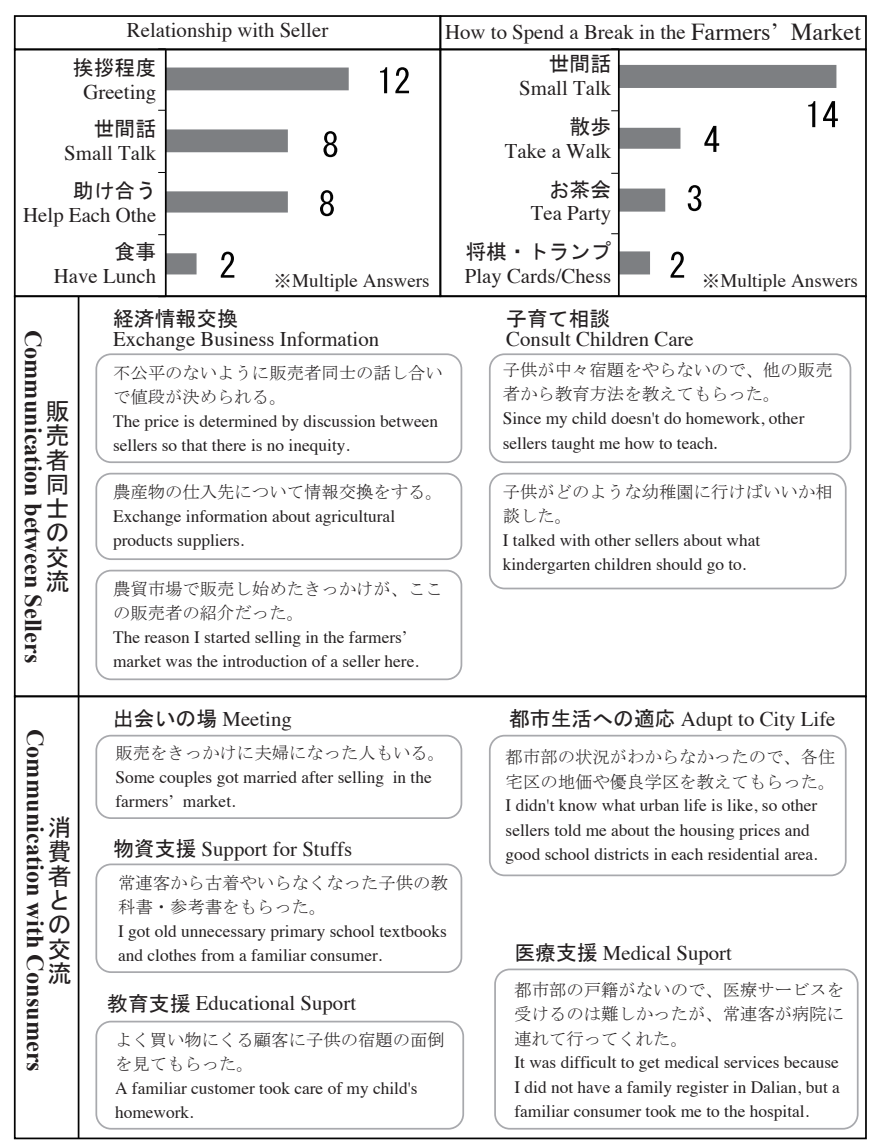

Fig.16 Comunication and activities of sellers in the farmers' market

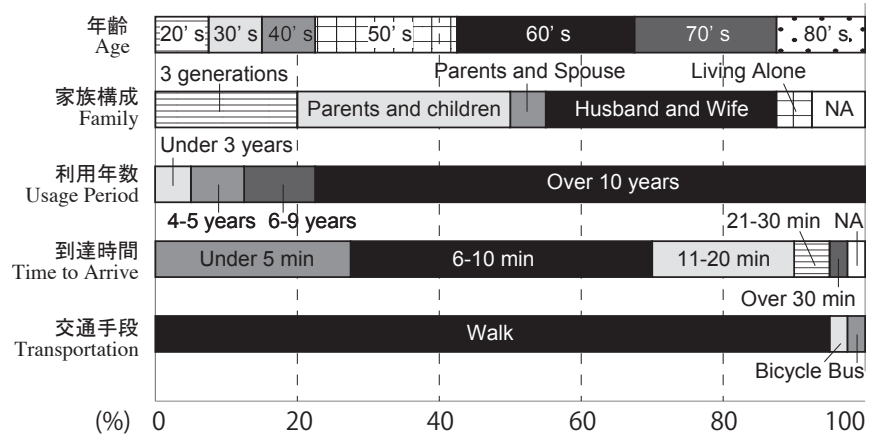

Fig.17 Basic Information about consumer $(n=40)$

(4) 販売者同士の交流実態 (Fig. 16より)

9 割の販売者が他の販売者との交流があると答えている。挨拶程 度の弱い関係もあれば、農貿市場での販売活動を通じて情報交換を 行い、互助関倸に発展するケースもある。販売者同士が販売価格の 相場を決めるため、商品の仕入先の情報共有などが主な交流内容で ある。一方、経済活動に関する情報に限らず、マイホームの購入や 子供の就学先、子育てなどについても情報交換が行われ、互いに都 市部の生活へ適応できるようにしている。他にも農貿市場での販売 活動を通じて知り合った販売者同士が結婚した事例も確認できた。 また販売時間以外にも特に販売者同士の交流が多く、お茶会やボー ドゲームなどを楽しむ人もいる。

(5) 販売者と消費者の交流 (Fig. 16より)

日頃より農貿市場を利用する消費者の一部は、販売者を積極的に 支援している。農村部出身の比較的収入が少ない販売者に子供の古 着や教科書を提供したり、子供の宿題の面倒を見たりするなど、消

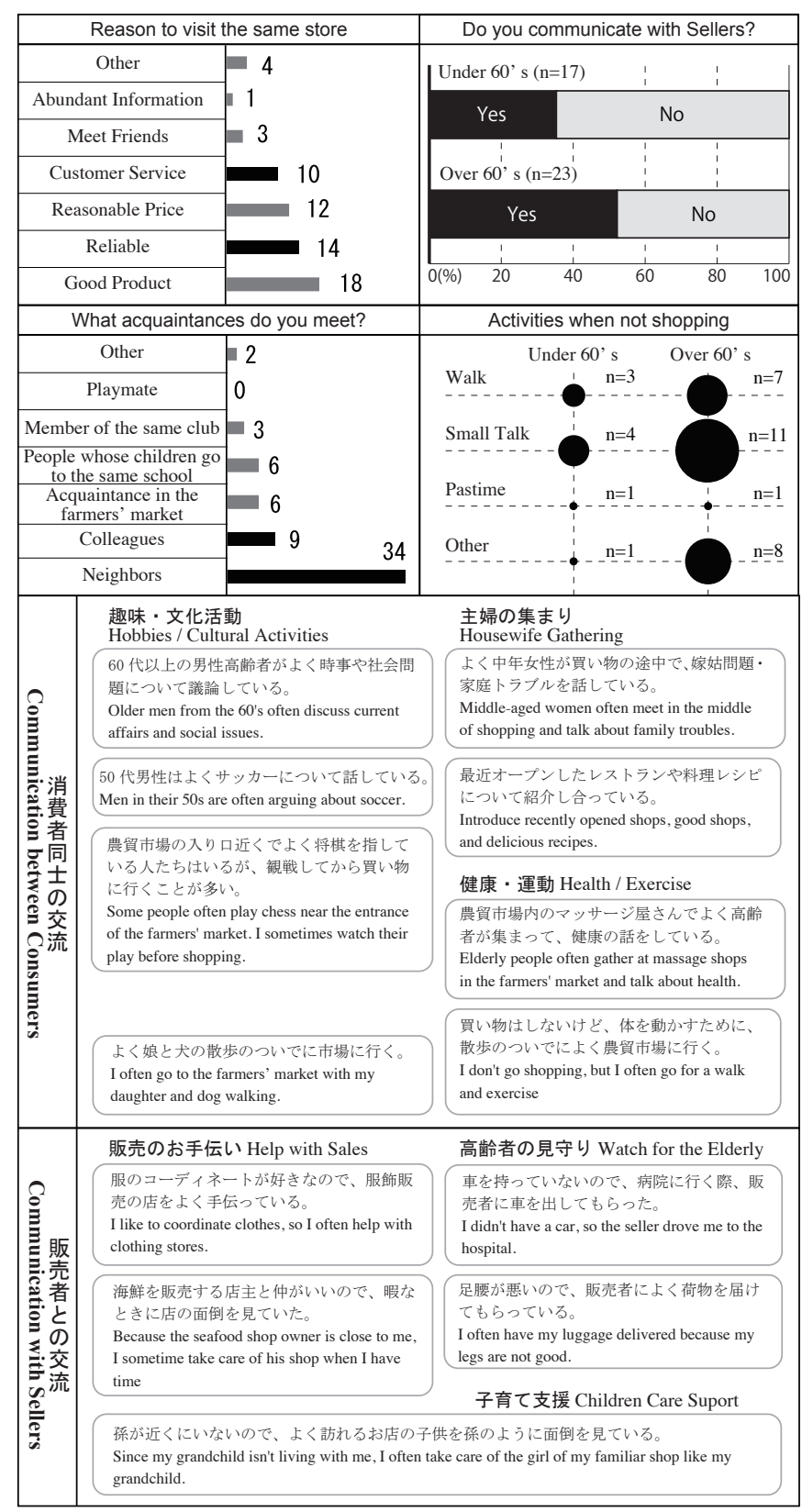

Fig. 18 Comunication and activities of consumers in the farmers' market

費者による物資の支援や子育て支援が行われている。また大連市の 戸籍がない販売者は医療サービスを受けることが難しいため、親し い顧客に医療サービスの受診や薬の購入を助けてもらう場合もある。

3）沙龍市場における多様な機能と活動（消費者について）

(1) 消費者の属性 (Fig. 17 より)

消費者の多くは徒歩で農貿市場に通い、10 分以下で到達できる人 が多いが、引っ越した後もバスで通う人もいた。またおよそ $75 \%$ 以 上の消費者は 10 年以上の利用歴があり、農貿市場ができた当初から 訪れる昔ながらの利用者が多数占めている。

(2) 消費者の農貿市場の利用 (Fig.18より)

消費者は買い物以外にも、散歩や会話をするために農貿市場に訪 れている。特に 60 才以上の高齢者は、軽い運動や健康のために農貿 市場まで出かけることが多い。また知人にも出会えるため、会話を するために訪れる消費者もいる。 
(3) 消費者同士の交流 (Fig. 18 より)

消費者の 9 割が農貿市場で知人に会うと答えている。農貿市場で 出会すのは、近所の住民が最も多く、次に職場の同僚や子供の学校 の父兄である。このように農貿市場は他所で知り合った人々の交流 のきっかけを提供している。また交流の場所は農貿市場の敷地内の みではなく、周辺でも趣味・文化活動が定期的に行われている。そ の活動内容は主にスポーツ・時事についての議論、カードゲームや ボードゲームなどが見られる。買い物をしなくても、集会への参加 を目的とする人々も農貿市場を訪れ、また買い物のついでに集会に 顔を出す消費者もいる。

(4) 消費者と販売者の交流 (Fig.18より)

消費者の 4 割以上は販売者との交流があり、定期的に特定の店舗 を訪れる。頻繁に通う理由として、商品の質、信頼性や接客態度が 挙げられる。より交流を深めている消費者の中には、販売を手伝う 人も見られる。例えば、販売者が不在のときに一時的に店の面倒を 見る消費者や、趣味のファッション・コーディネートを活かし、服 飾の販売の助言をする消費者もいる。足腰が弱い高齢の消費者は、 販売者に購入した商品を届けてもらったり、病気の時に車で病院ま で連れて行ってもらったりしている。一方、高齢の消費者は代わり に販売者の子供の面倒を見るという事例もあり、高齢者を中心に販 売者との互助関係が築かれている。

\section{4-3 考察}

農貿市場とスーパーマーケットの選択要因は、それぞれ買い物頻 度と年齢層である。若年層を中心にスーパーマーケットへの安心感 がある一方、市場に対して食の品質に対する不安を感じ、商業施設 としての環境改善と安全性を求めている。一方、人と人の距離がよ り近い沙龍市場のような農貿市場では、販売者と消費者の間にスー パーマーケットでは見られない様々な活動が生まれている。

販売者の中には大連市外の地方農村出身者も含まれ、都市部の暮 らしへの理解が不十分な場合が多いが、農貿市場での販売活動は販 売者の都市生活への適応につながる。また農貿市場は消費者にとっ て、文化交流の場の形成、高齢者の健康維持や見守りなどの側面を 持ち、心身の豊かさを高めている。ここから沙龍市場という旧式な 農貿市場は経済活動を行う商業施設や食料供給拠点として機能する と共に、買い物を通じて販売者と消費者の双方によって社会的関係 が築かれ、より多面的な役割を果たしていると言える。

\section{5 章 まとめ}

農貿市場は農産物の取引の自由化に伴い、交易の場として 1980 年 代後半に建設された。初期は農産物の取引が目的であったが、2000 年代では、農産物のみではなく、様々な商品販売が可能な商業施設 となった。そのため地域コミュニティでは他の商業施設とは一線を 画す存在として発展してきた。

本研究では大連市沙河口区の 25 か所の農貿市場とその周辺環境に ついてそれぞれクラスター分析を行い、5つの類型を導き出した。 その中でも旧式の農貿市場が中心の MCL2 タイプに着目し、農貿市場 での消費者・販売者の活動、その近隣コミュニティに果たす役割を 分析した。その結果、今回の調查対象である沙龍市場という旧式の 農貿市場は、農村部からの出稼ぎ労働者の受け典となり、都市生活 に適応させる側面を持つことが明らかとなった。また販売者は農貿

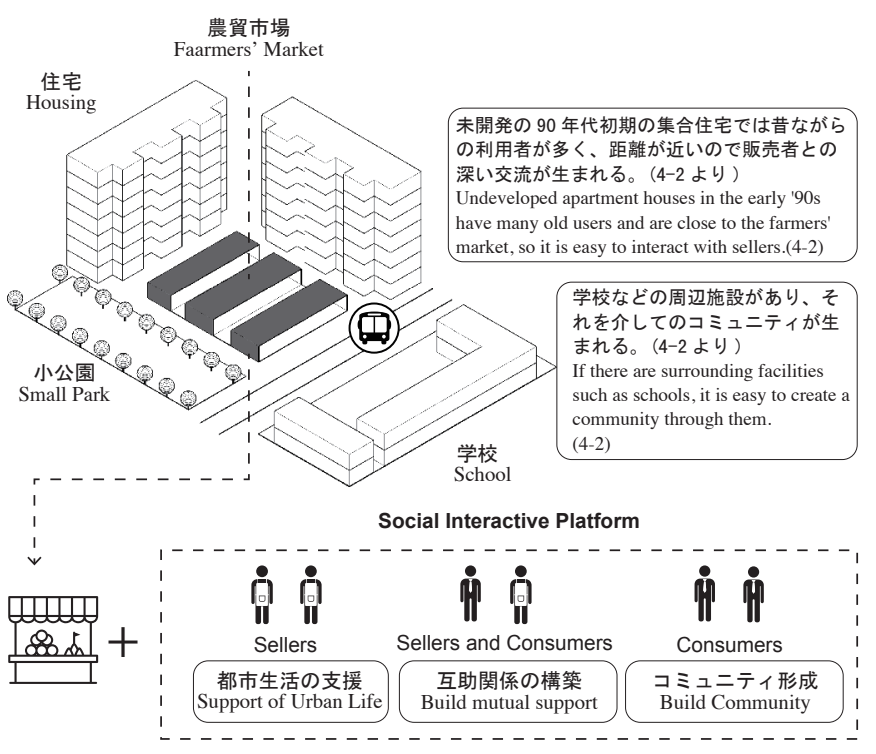

Fig.19 Summary of the farmers' market

市場での販売・交流活動を通じて、「経済情報の交換」、「生活水準の 向上」、「医療・物資・教育の支援」など近隣コミュニティと社会的 互助関係を形成していた。一方、消費者にとっての農貿市場は単な る買い物の場所だけではなく、「趣味・文化活動」、「健康維持」、「高 齢者の見守り」といった副次的な役割も果していた。

農貿市場の建設が始まってから 30 年以上経った現在、沙龍市場の ような農貿市場は「販売者の都市生活への支援」、「住民のコミュニ ティ形成」「地域における互助関係の構築」などの社会関係形成を 促すプラットフォームとしての機能を有するようになったと言える。 しかし、このような機能は商業施設の副次的な役割は消費者・経営 者から重視されず、スーパーマーケット化する農貿市場も多く見ら れる。

一方、本研究の対象市場は周辺建物と隣接し、住宅地内に位置寸 る昔ながらの空間構成を維持する農貿市場である。そのため対象市 場は、そこに関わる様々な社会的な活動を下支えする空間の柔軟性 を持ち合わせ、社会関係の形成の場となっていた（Fig.19）。これか らの農貿市場は商業的機能の環境面・安全面の改善に加え、社会関 係形成のプラットフォームとしての機能・役割を維持し、地域住民 の需要、ライフスタイルの変化に合わせて、段階的に施設を更新し ていく必要がある。そして将来的には、「商業 $+\alpha 」$ の施設として地 域社会に根付くことで、農貿市場の持続的な発展が可能になると考 えられる。

注

注 1)「単位 (danwei)」とは職場を意味し、計画経済体制における職場を中心 とした人々の共同体 (working unit) を指す。その種類として、政府機関、 国営企業、事業単位（病院、学校など）などがあり、同じ職場に所属す る従業員は同様なサービスを受けられ、医療保障、住宅の分配など多様 なサービスが提供されていた ${ }^{14)-16) 。 ~}$

注 2)「社区」(Community の中国語訳）とは改革開放以降の地域住民の社会生 活共同体を指す。また「社区居民委員会」という末端行政・住民組織が 管轄する行政区画も表す ${ }^{13), 14)}$

注 3）「農貿市場」(菜市場) は青果物や魚介類・肉類などを販売している市場 である。本研究の対象は小売を中心とする複数の個人から構成されるも のとする。

注 4）中国では「スーパーマーケット」は「超市」と表されている。 
注 5）「菜藍子」は中国語で「野菜の籠」を意味している。

注 6）例えば鄭州では 8 年間の間に市街地面積が拡大したのにも関わらず、半 分以上もの農貿市場が姿を消した ${ }^{17)}$ 。

注 7) 北京では全市に 9000 箇所以上 (2019 年) の野菜の小売拠点がネットワー クを形成し、2019 年度上半期でも前年度より 141 箇所増加している ${ }^{13)}$ 。

注 8）大連市政府が 2018 年 9 月 30 日に公布した「大連市政府弁公庁が『菜藍 子』商品の市場流通能力の建設を実施するための意見」の内容より。

注 9）「社区サービス」は社区内の住民に向けたサービスであり、日常生活の 質の向上を目的としている。その内容は福祉、医療、文化、環境など多 岐に渡る ${ }^{13)}$

注 10) 北京では 1995 年から 2000 年にかけて、市民が単位に所属している割合 は $91.2 \%$ から $68.9 \%$ に減少した ${ }^{16)}$ 。

注 11）中国商務部は 2005 年に「我国の社区商業の発展に関寸る指導意見」、 2009 年に「社区商業の業務の向上に関寸る通知」を公布した。

注 12) 沙河口区の境界線は高徳地図より取得。

注 13) 最大道路幅は市場に隣接する道路の最大車線数を用いた。

注 14）参考文献 19）より、中心居住区に位置する農貿市場の利用半径は 800m と設定されている。また「城市居住区規劃設計標準（GB50180-2018）」 より 10 分圈内に各種施設の配置を推奨しているため、農貿市場の周辺 環境も市場から徒歩 10 分範囲内 (800m 圏内) のエリアとした。

注 15) 施設機能について次のように分類した。商業 : 飲食店・ホテル・生活サー ビス、美容・ショッピング、オフィス・ビジネス：金融・不動産・一般 企業、娛楽 : 観光地・レジャー・運動、教育文化 : 学校・メディア、公 共：医療、交通、行政機関。

注 16) 参考文献 20）より Simpsonの多様性指数は生物の種組成の豊富さと均等 さを示すものである。本研究ではこの指数を用いて市場の周辺機能の多 様さを評価し、式は以下の通りである。

$\mathrm{D}=1-\Sigma \mathrm{Pi}^{2}(\mathrm{Pi}=$ 各機能数が全体機能数を占める割合 $)$

注 17) 土地利用は大連市都市総計画図 (2010-2020, 2017 年版) より、住宅価格 は中国の中古不動産ウェブサイト「Beike Network (贝壳网)」よりデー 夕を取得。

注 18) 数量化 3 類の分析結果の 詳細はAppendix1のよう に示される。第 1 軸は值 が負になると，「加工食品」 や「魚介・肉類」などの 食品が，值が正になると 「鍵・靴」や「日用品」な どの工芸品が多くなる。 第 2 軸は值が負になると, 「青果物」や「日用品」な どの生活必需品が，值が 正になると「服飾」や「酒」 などの嗜好品が多くなる 傾向がある。

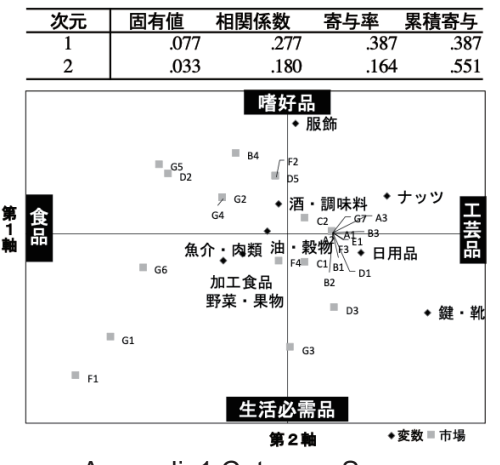

Appendix 1 Category Score

\section{参考文献}

1) S. Eguchi : The Urban Community Construction and Social Management in Comtemporary China : Examining the Shandong Province, Shimane Journal of Policy Studies, No.23, pp.109-121, 2012.03. (in Japanese)

2) W. Zeng and L. Zhang : Explore the Management Strategy of the Farmers' Market against the Background of Urbanization[Translated from Chinese], Industrial \& Science Tribune, Vol.17, No.13, pp.276-277, 2018 (in Chinese) 曾吴丹, 徐梅: 城镇化背景下的农贸市场管理策略探索, 产业与科技论坛, 第 17 卷, 第 13 期, pp. 276-277, 2018

3) W. Zeng and M. Xu : Analysis of the Prospect of "CCIS" and the Development Trend of the Farmers' Market[Translated from Chinese], Economic Research Guide, No.13, pp.16-17,2018 (in Chinese)

曾吴丹，徐梅：“农改超” 前景分析与农贸市场的发展趋势研究，经济研究 导刊, No. 13, pp. 16-17, 2018

4) Y. Ma and J. Yang : The Necessity, Principle and Method of Conversion of the Traditional Farmers' Market[Translated from Chinese], Rural Economy, No.2, pp.16-18,2005.02 (in Chinese)

马云甫, 杨军: 传统农贸市场改造的必要性, 原则与模式, 农村经济, 第 2 期, pp. 16-18, 2005. 02

5) Y. wu : Problems and Countermeasures in the Operation of China's Urban and Rural Farmers' Market[Translated from Chinese], Issues in Agricultural Economy, No.5, pp. 15-18, 1996 (in Chinese)

吴一平: 我国城乡农贸市场运行中存在的问题及对策, 农业经济问题, 第五期, pp. 15-18, 1996

6) H. Guo : Discussion of Reforming the Farmers' Market under the Competition with a Supermarket[Translated from Chinese], China Market, No.10, Vol.965, pp.128-129, 2018 (in Chinese)

郭海生：浅谈基于超市竞争下的农贸市场改革，中国市场, No. 10, Vol. 965, pp. 128-129, 2018

7) Q. Zeng and Q. Ding : How to Convert the Farmers' Market into a Supermarket [Translated from Chinese], Jiangsu Commercial Forum, No.8, pp.5-7, 2005.08.30 (in Chinese)

曾庆均，丁谦：农贸市场改建超级市场之路，江苏商论，第 8 期，pp. 57, 2005. 08. 30

8) D. Chen, Z. Zhang and J. Li : Accessibility Based Grocery Market Layout Technique In Zhuhai, Planners, No.5, pp.122-127, 2018. (in Chinese)

9) N. Wang and L. Zhang : A Study on the Behavior of Urban Residents' Choice of the Retail Terminal of Fresh Vegetables in Small and Medium-sized Cities: An Empirical Analysis Based on the Ordered Multivariate Logit Model, Journal of Business Economics, No.9, Vol.299, pp.5-13, 2016.09 (in Chinese)

10) Z. Rao and Y. Wang: Practice and Ideas on Intelligent Application of the Farmers' Market [Translated from Chinese], China Economist, No.9, pp.3637,2018 (in Chinese)

饶志文, 王勇强: 农贸市场的智慧化应用实践与思考, 经济师, 第 9 期 , pp. 36-37, 2018

11) R. He : The Research on the Planning and Arrangement of Wet Market in Changsha, Hunan University, pp.26, 2006.05 (In Chinese)

12) Shanghai Municipal Commission of Commerce : Update Standardized Farmers' Markets in Shanghai to 2.0 ver. [Translated from Chinese], 2017.03.23, <http://sww.sh.gov.cn/swdt/242268.htm>, Accessed 2019.09.07 (in Chinese)

13) M. Bao : The Current Situation and Problems of Community Services for Older People : A Case Study of PuDong District in Shanghai, The bulletin of Department of Health and Social Services, Hiroshima International University, No.6, pp.25-36, 2010.03.31 (in Japanese)

14) H. Ye, Q. Chen, T. Sugiman : Forming Resident Network Towards Community Creation in Urban China : Political and Historical Considerations based on a Case Studies, Journal of Group Dynamics, Vol.34, pp.288-319, 2017.07. 31 (in Japanese)

15) Y. Yang : An Analysis of the Urban Economic System in China: From the Viewpoint of the Spatial Economy, Hiroshima University of Economics 50th Anniversary Bulletin Paper, pp.293-330, 2017. 07/31.(in Japanese)

16) A. Zhu, J. Song and S. Tanaka : The Development of Community building in China: Transformation of Urban Structure in Chinese Cities[Translated from Japanese], The Annals of Japan Association for Urban Sociology, pp.81-96, 2003 (in Japanese)

朱安新，宋金文，田中重好：中国におけるコミュニティづくりの展開：中 国都市の構造転換，日本都市社会学会年報，第 2003 巻，第 21 号，pp. 81 96, 2003.

17) W. Wei : Will the vegetable markets in Chinese cities disappear?[Translated from Chinese], Today's Topic, No.4339, 2018.10.05, < https://view.news. qq.com/original/intouchtoday/n4339.html>, Accessed 2019.09.06 (in Chinese)

18) Q. Ma : Vegetable Retail Stores in Bejin Exceeded over 9,000 : Beijing's "Vegetable Basket" Become More and More Full [Translated from Chinese], Beijing Daily, pp.1, 2019. 08. 11 (in Chinese)

马婧：北京市各类蔬菜零售网点超九千个：北京 “菜篮子”越装越满，北京 日报, pp. 1, 2019.08. 11

19) L. Wan, Y. Bi, M. Liu : Study on Special Layout of Small Farmers' Market in Small and Medium Cities : Take Boshan District of Zibo City as an Example, 2017 Urban Development and Planning Proceedings, pp.1-5,2017.07 (in Chinese)

20) I. Matsunaga, K. Tanoue, S. Kurose : A Quantitative Analysis of Street Facades Using Simpson's Diversity Index, Journal of Architecture and Planning (Transactions of AIJ), Vol.80, No.714, pp.1863-1873,2015.8(in Japaanese) 


\title{
SUSTAINABLE DEVELOPMENT OF THE CHINESE FARMERS' MARKET FOCUSING ON ITS SPATIAL FEATURES AND ROLES IN LOCAL COMMUNITY
}

\author{
- A case study of Shahekou District in Dalian - \\ YuanjiSHI $^{* 1}$ and Tetsuya YAGUCHI ${ }^{* 2}$ \\ ${ }^{1}$ Urban Project Department, Nikken Sekkei Ltd., M.Arch. \\ ${ }^{2}$ Prof., Dept. of Arch., Graduate School of Creative Science and Engineering, Waseda Univ., Dr.Arch.
}

\begin{abstract}
After China has been transformed from a planned economy to a socialist market economy since 1978, the Chinese farmers' market has supported people's daily life as an essential facility for providing agricultural products. However, the number of farmers' markets was decreasing from the late 2000s because of the penetration of supermarkets. Although nowadays the option of shopping becomes more diverse, it is still playing distinctive roles in local society. Therefore, the sustainability of the farmers' market merits discussion through the investigation of its characteristics. This paper explores the originality of the farmers' market by investigating the pattern of its spatial features and observing people's various activities and relations there. The included case study utilizes the example of Shahekou District, Dalian, which features distinctive farmers' markets. Through classifying the spatial patterns quantitatively and describing people's activities, the results obtained are as follows.
\end{abstract}

\section{1) The spatial features of the farmers' market}

The building of recent farmers' markets constructed after the 2000s is similar to typical large scale grocery stores seen in China and mostly located in the high-density building area under development. On the other hand, the building of most farmers' markets constructed from the 1980s to the 1990s is composed of stall-type buildings and surrounded by mid-rise residential buildings or schools. These old type markets are mostly locating in the undeveloped area with good access to public transportation where the plot pattern is relatively complicated. The scale is a middle or large class comparing with the recent farmers' market. From the results above, the old type farmers' market composed of stall type buildings is more familiar to local users and residents and tends to generate extra changeable space flexibly. These spatial features seem to facilitate informal communication and foster a sense of community.

\section{2) People's activities and relations in the farmers' market}

The factors that affect customers to choose the farmers' market or supermarket are related to their shopping styles and age. While the young generation trusts the product of supermarkets, they are worried about the quality of food in farmer's markets and demand to improve the shopping environment and food security. Especially in the old farmers' market such as the subject of this survey (Shalong Market), however, various social-economic activities could be found because of the closer social relationship between customers and sellers there. From the results of the questionnaire and observation, people's activities in the farmers' market could be defined as "Exchange of Economic Information", "Improvement of Life Quality", "Medical and Educational Support", "Cultural Activities", "Support for Old Customers", and "Health Maintenance".

After 30 years from the introduction of a socialist market economy, the farmers' markets present potential of become a mature social interactive platform. The function is not just shopping but also includes "Support of Urban Life", "Build Mutual Support in Local", and "Create Community of Residents". Although these aspects of the farmers' market are usually ignored, it is essential for its sustainable development in the future to remain the function as a "Commercial + $\alpha$ Facility ". 